\title{
Food Loss and Waste Prevention Strategies from Farm to Fork
}

\author{
Rosalinda Nicastro and Petronia Carillo*(D) \\ Department of Environmental, Biological and Pharmaceutical Sciences and Technologies, University of Campania \\ “Luigi Vanvitelli", Via Vivaldi 43, 81100 Caserta, Italy; rosalinda.nicastro@studenti.unicampania.it \\ * Correspondence: petronia.carillo@unicampania.it; Tel.: +39-0823-274562
}

Citation: Nicastro, R.; Carillo, P. Food Loss and Waste Prevention Strategies from Farm to Fork.

Sustainability 2021, 13, 5443.

https://doi.org/10.3390/su13105443

Academic Editors: Felicitas Schneider, Stefan Lange and Thomas Schmidt

Received: 26 April 2021

Accepted: 11 May 2021

Published: 13 May 2021

Publisher's Note: MDPI stays neutral with regard to jurisdictional claims in published maps and institutional affiliations.

Copyright: (c) 2021 by the authors. Licensee MDPI, Basel, Switzerland. This article is an open access article distributed under the terms and conditions of the Creative Commons Attribution (CC BY) license (https:// creativecommons.org/licenses/by/ $4.0 /)$.

\begin{abstract}
About one-third of the food produced globally for human consumption is lost or wasted each year. This represents a loss of natural resources consumed along the food supply chain that can also have negative impacts on food security. While food loss occurs between production and distribution and is prevalent in low-income countries, food waste occurs mainly at the consumer level, in the retail and food service sectors, and especially in developed countries. Preventing food losses and waste is therefore a potential strategy for better balance food supply and demand and is essential to improve food security while reducing environmental impact and providing economic benefits to the different actors in the food supply chain. In this context, we specifically provide an overview of case studies and examples of legislation from different countries and actions carried out by the various actors in the food chain and by non-profit organisations to effectively prevent and or reduce food loss and waste. We also outline current limitations and possible research avenues. We conclude that the comparison and the integration of knowledge, and the awareness of where along the food chain, for which foods and in which countries the greatest losses are produced, is essential to decide where and how to target efforts in the most effective way.
\end{abstract}

Keywords: food waste; food loss; policy; legislation; SDG 12.3; national strategies; food supply chain; food redistribution; multi-stakeholder cooperation

\section{Introduction}

One-third of the food produced globally for human consumption, corresponding to about 1.3 billion tonnes, is lost or wasted each year along the food supply chain (FSC) [1]. FSC includes the series of related activities used to produce, process, distribute and consume food [2]. Each stage of the FSC consists of several operations, both agricultural and industrial, within which different types of losses and waste occur. Understanding the causes and identifying why food is lost and wasted is a key step in improving resource efficiency in the long term [3]. Losses along the FSC generally depend on socioeconomic, biological and/or microbiological, chemical or biochemical, mechanical and/or environmental factors [4]. Some of these are related to the technologies, methods, techniques and practices employed and used by the several actors in the food system, such as mechanisation, agronomic practices and farm management practices. Other factors are related to natural causes, such as the presence of insects, pests, mould, temperature conditions and humidity, or to the socio-economic environment, such as access to market information. Indeed, the combination of these elements can considerably influence food loss and waste (FLW) [5,6].

Urbanisation is one of the causes linked to the production of large quantities of food waste, as it has led to the expansion of the FSC to meet the population's food needs [7]. Therefore, it is important to improve storage, transport and sales techniques and conditions to avoid losses and waste due to the increasing distance between the production site and the final consumption site [8]. To confirm these global trends, Parfitt, et al. [9] considered the differences in post-harvest losses between developing, transition and developed countries. As developing countries grow economically, the condition of their infrastructure and 
techniques improves and the nature of their food losses changes. With rudimentary post-harvest infrastructure, most food losses occur at the harvest and post-harvest stages, whereas in countries with more advanced infrastructure, food waste occurs at the retail and consumption levels [10]. So, the richer a country becomes, the more its food losses nature is voluntary. The amounts of losses also depend on a change in diet composition especially in countries with transition economies such as India, Russia or Brazil, which, as a result of increasing income, consume more and more fresh products such as meat, fish and fruit and vegetables which are more perishable [11]. Furthermore, in a scenario of expanding commerce and large-scale distribution, many retailers in emerging countries such as Asia, South America and Africa are being replaced by supermarkets [12]. In addition, there is an increasing trend towards higher quality products, which has a significant impact on the amount of food waste produced [13]. FLW vary according to the stages of the FSC: the production stage is considered to be the most important point for food loss, particularly during product processing (interrupted production; product change, human error, etc.) while at the household level the most waste occurs [14]. However, there are also differences depending on the type of raw material. Generally, as fresh foods that are easily perishable, fruits and vegetables, partly due to their high water content, are characterised by higher levels of loss than cereals and pulses [15]. The high humidity of the climate can have a negative impact on food preservation, especially in developing countries where there are more losses during the early stages of the food chain, also due to an increase in production as a result of the need to follow the seasonality of products, which results in a lack of sales of excess goods. However, errors in management and in adopting the correct methods of harvesting, storage, processing, etc., can also affect levels of vegetable products losses. Meat losses, on the other hand, are less pronounced and show smaller differences between countries [11].

Is it still possible to prevent food losses and waste and find a better balance between food supply and demand, reducing the environmental impact and providing economic benefits to the various actors in the food supply chain? To answer this question, in our review study we define the meaning of the terms "Food loss" and "Food waste" along the various stages of the food chain, trying to quantify their amounts. We describe the measures currently adopted for preventing and reducing food loss and waste, also describing their limits and the possible alternative approaches to follow. Moreover, we provide an overview of the case studies and examples of legislation of different countries and of the actions carried out by the various actors in the food chain and by non-profit organisations to effectively prevent and/or reduce food losses and waste.

\section{Food Loss and Food Waste along the Food Supply Chain}

\subsection{Definition of "Food Loss" and "Food Waste"}

In order to understand what is meant by food loss and food waste, it is important to refer to the correct definitions of "food". With the latter term is indicated any substance or product, whether processed, partially processed or unprocessed, intended to be, or reasonably expected to be, consumed by humans [16]. Food includes beverages, chewing gum and any substance, including water, intentionally incorporated into food during its manufacture, preparation or processing [17]. Therefore, it should be possible to distinguish between food loss and food waste according to the stage where they occur along the FSC.

There are several products to consider and definitions proposed in the literature for the phenomena of FLW. The products to be considered are only those agricultural products originally intended for human consumption, ready for harvesting or post-harvesting [18]. However, the terminology used may be different. The FAO [18] uses the term "food waste" only in reference to the last stages of retail and consumption, and it can be distinguished according to the destination, the edible part and the nutritional value of the food lost or wasted. Moreover, the FAO [18] considers also the various problems associated with FLW: the impacts on the environment, the economy, on health and food safety. Many definitions also focus on the difference between "quantitative" and "qualitative" loss. Conceptually, 
it is easier to define and measure quantitative losses and waste than qualitative ones. Quantitative FLW refers to the decrease in the mass and volume of food for human consumption, while qualitative FLW refer to the decrease in the chemical/physical and/or organoleptic characteristics of food for human consumption [2,19]. In both previous cases, there may be a consequent economic loss: in the former case, farmers will have less volume or weight to sell, and in the latter case, the price offered for their products will be lower than that offered for higher quality food products $[15,20]$. In addition, with regard to the loss of quality of a product, there will also be a nutritional loss with a consequent health risk for the consumer [21]. The FAO [2] has produced a definitive picture of FLW as a global reference for stakeholders to use within their own operational context. Food loss is defined as the decrease in the quantity and quality of food resulting from the decisions and actions of food suppliers along the FSC, excluding retail, food services and consumers. Food losses therefore occur at the production, post-harvest and processing stages along the food chain. Food waste, on the other hand, refers to the decrease in the quantity and quality of food resulting from the decisions and actions of retailers, food service providers and consumers. Both depend more on the causes of food loss or waste than on the stage at which it occurs along the food chain. Causes that can be identified in the poor protection and conservation of the product along the FSC or refusal for product surplus [22,23].

However, the European Commission's project FUSIONS “Food Use for Social Innovation by Optimising Waste Prevention Strategies", whose aim was to make Europe more efficient in reducing food waste, applied the term "food waste" to all stages of the FSC, without differentiating between edible and non-edible parts of foodstuffs, nor considering products intended for animal feed or alternative uses. In fact, any food, or inedible parts of food, sent to animal feed, bio-material processing or other industrial uses was included in the terms "valorisation and conversion". Thus, the term "food waste" described "any food, and inedible parts of food, removed from the FSC to be recovered or disposed (including composted, crops ploughed in/not harvested, anaerobic digestion, bio-energy production, co-generation, incineration, disposal to sewer, landfill or discarded to sea)" [24].

\subsection{Food Loss during Cultivation and Harvest}

In the cultivation and harvesting phases, various factors contribute to food losses such as biotic (e.g., insects and pests) and abiotic (e.g., climatic conditions) stresses, causing food waste to several degrees depending on the type of crop and where that crop is produced. In fact, more modern cultivation and harvesting techniques in developed countries result in higher yields than in non-industrialised countries where lack of knowledge of the best techniques to adopt at these stages and of appropriate equipment is the primary cause of losses [11,25].

Rapid spoilage of goods is caused by an attack of pathogens that can act even faster if the foodstuffs are already damaged or have injuries sustained during the various stages of harvest, transport or sale $[15,26]$. This is especially true in developing countries, which often have inadequate infrastructure (such as barely passable roads) and non-ideal storage facilities [27], and where the losses incurred are also due to a lack of adequate knowledge and sound management practices in warehouses, as well as limited technical, financial and managerial resources [15].

Improper handling of products during harvesting, including the use of large machinery, can cause damage and injuries that facilitate the entry of pathogens that lead to faster deterioration of crops, especially roots and tubers. This is one of the major causes of loss in farms that, especially in industrialised countries, will produce more than the effective demand also to prevent damage caused by unpredictable weather events [28]. This results in surplus crops being sold to processors or used as animal feed. However, this is not economically advantageous as prices in these sectors are lower than in retail [2].

Food losses during the harvest stage also depend on harvesting methods and timing. In developing countries, in particular, food can be lost as a result of premature harvesting: due to food shortages or desperate need for money, farmers are sometimes forced to har- 
vest crops too early, affecting not only market value but also nutritional value, resulting in food that is unfit for consumption being wasted [29]. However, food losses can also occur following a delay in harvest, as products left in the field after reaching maturity are susceptible to attack by pests, rodents and fungi. This results in an increase in decay and a consequent decrease in quality as well as increased susceptibility to damage during transport [25]. Knowing when to produce and harvest different crops is of crucial importance as these are affected by weather conditions, which are often unpredictable. Indeed, high temperatures can compromise the proper formation of flowers and fruit and they can be sunburned. Moreover, not only high temperatures, but also colder climates can cause increased action by insects and fungi, increasing the likelihood of disease and forcing farmers to use pesticides [15]. Losses can affect not only field products, but also meat as a result of diseases that can affect animals due to poor herd management, temperatures and access to water, increasing overall mortality [30].

\subsection{Food Loss during Post-Harvest}

The largest post-harvest losses take place in the storage stage and are easier to estimate and prevent [4]. As previously mentioned, the causes of food losses vary across the world and between the same types of commodities. For example, low-income countries cause loss of fresh fruit and vegetables mostly as a result of inadequate infrastructure or lack of cold storage compared to industrialised countries. As a result, products are consequently destined for disposal due to a shorter shelf life and thus a higher perishability and will [31]. This can also happen if the crop remains in a pile waiting to be transported and thus also exposed to heat and direct sunlight due to too long a period of waiting between the different stages of the FSC [15].

During post-harvest, increased losses can be linked not only to the use of inadequate equipment, but also to the use of unsuitable packaging for a particular fruit and vegetable product, causing physical damage that decreases the shelf life of the harvest. In fact, interviews carried out with operators of some farms have confirmed the fact that postharvest losses also occur as a result of human errors deriving mostly from a lack of knowledge in the correct handling of different products [11]. Many foods, especially fruit and vegetables, have to follow standards of size, shape and quality to meet the demands of the end consumer, and these are often not respected as a result of processing errors or damaged packaging. This leads to the throwing away of food that is still viable because these errors are not necessarily synonymous with a decrease in taste, nutritional value or food safety [14]. However, these products with shape or "cosmetic" defects not usable for the fresh market could be canned or frozen or, if broken, crushed or seriously damaged, diverted to the industry for processing (for juice or puree) or treatment (freshcut). Furthermore, waste can be avoided by allowing volunteers to collect residual streams of products that, due to shape or cosmetic problems, cannot be appropriately wrapped and packed and to distribute them through food banks [32].

Stuart [33] studies were based on understanding the influence of standards on food loss levels. In particular, on one British farm Stuart found that large quantities of carrots were being used for animal feed production as they were slightly declining [33]. The finished products, before being packaged, pass through machines that search for aesthetic defects (colour, size, shape) so that the products in the packages are all uniform, which is important for consumer satisfaction.

The processing of different products requires quality standards that must be respected especially for those foods intended for human consumption. So, for example, cleaning the line for the production of two different products can be important to prevent residues from the previous processing from affecting the quality of the subsequent foodstuffs and therefore to avoid the production of waste [14]. In many developing countries, however, it is often not cost-effective to invest in storage or processing facilities because the seasonality of produce means that it is not used all year round. Thus, the lack of infrastructure to store fresh food to meet demand means that food losses increase [34]. 
In order to maintain the required standards, products in damaged or incorrectly sealed packaging are lost, as these errors could lead to a decrease in the quality of the foodstuffs with consequent damage to the processors who would be rejected by the buyers [14].

\subsection{Food Loss and Waste during Distribution, Retail and Consumption}

During transport, losses can occur due to damage to packaging, which makes products more susceptible to spoilage, but also due to the long distances often present between the place of production and the place of sale. This leads not only to higher transport costs, but also to the possibility of higher losses due to bad roads or unsuitable means of transportation [15].

At the retail stage, it is important to make demand forecasts in order to avoid products remaining unsold before the recommended use-by date. This is complicated, however, as demand depends on the seasonality of the products, promotions offered by supermarkets or the time of year [11].

In developed countries, supermarkets offer a large number of goods of different types and brands to meet consumer demands. However, this increases the likelihood that products will not be sold before their use-by date, leading to higher levels of waste [35].

Correct storage and display methods at retail level are also important, and this is why retail staff must be trained. This is mostly the case in both developed and non-industrialised countries: food wastage occurs mostly due to the poor hygienic conditions of markets which also lack the necessary facilities for cooling and thus proper preservation of food [11]. In these countries, however, poverty means that levels of wastage are very minimal, so they hardly ever occur at household level [15]. In contrast, in rich countries the consumer can "afford" to waste food, not only because of the higher income, but also because there is a high amount of food available from retail shops and restaurants [36]. Restaurants offer buffets where you can take as much food as you want at a fixed price, which encourages consumers to take more food than they actually need; retail shops offer cheap deals that encourage over-purchasing or offer ready-to-eat food in too large a portion [37].

In addition to waste due to poor planning of (over)purchases, consumers often confuse labels regarding "use by" or "best before" and do not pay attention to storage instructions on the packaging. As a result, food is often thrown away both because it is not consumed before it has passed its "best by" date and also because many goods in retail shops remain unsold since consumers prefer to buy food with a longer shelf life [38].

Underlying all of this is a lack of complete knowledge about levels of waste and its impact in both economic and environmental terms [11].

\section{Quantifying Food Losses and Waste}

In order to understand where action needs to be taken to prevent or reduce levels of food waste, in terms of both public and private investment and policy action, it is important to know where FLW occur throughout the FSC and the impact they have. However, quantifying losses is quite a challenge as the food waste generated within the different food chains depends on many factors that do not allow for accurate estimates [9], such as highly variable human errors [13].

The project FUSIONS conceived a "Food waste quantification manual to monitor food waste amounts and progression" [39]. The manual provided to Member States a set of practical guidelines to understand the quality and quantity of food waste at different stages of the supply chain. According to the data on food waste generated in the European Union, most of this is generated at the level of households and the processing sector ( 47 million and 17 million tonnes, respectively) accounting for $72 \%$ of total food waste in the EU. The remaining part is contributed by food services, responsible for the generation of 11 million tonnes of waste, or $12 \%$ of the total, followed by the production and retail and wholesale stages (9 and 5 million tonnes, respectively) (Figure 1) [39]. 


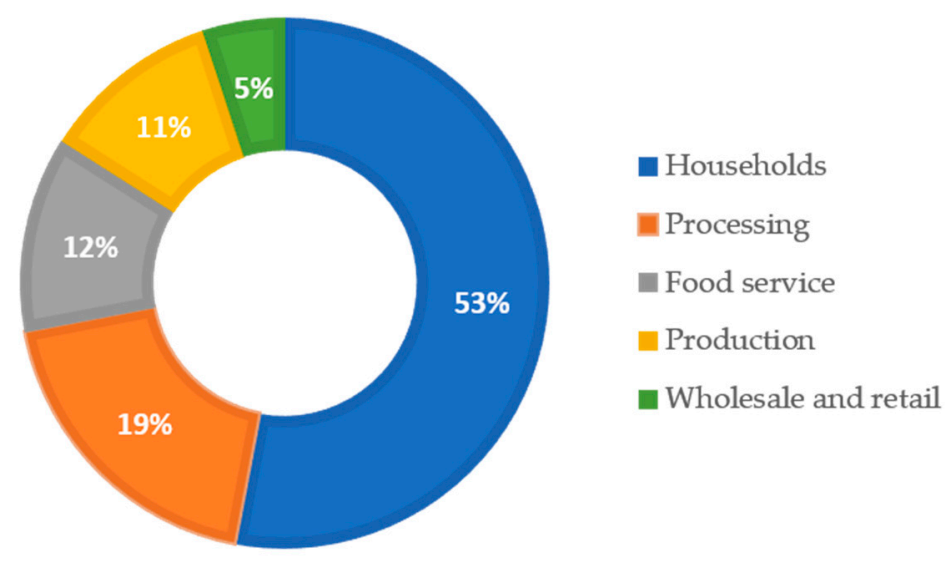

Figure 1. Food waste generated in European Union at different stages of the food supply chain.

In addition, the FAO, in collaboration with the United Nations Environment Programme (UNEP), is seeking to make effective the adoption of two indices to more accurately estimate (i) how much food is lost along the food chain up to the retail stage (the latter stage not included), the Food Loss Index (FLI), and (ii) how much is then wasted by retailers or consumers, the Food Waste Index (FWI) [2]. These indices are part of the more general Global Food Loss Index (GFLI) and allow monitoring of progress towards Sustainable Development Goal 12 (SDG Target 12), the purpose of which is to "ensure sustainable consumption and production patterns", with the more specific Target 12.3 aiming "by 2030, to halve per capita global food waste at the retail and consumer levels and reduce food losses along production and supply chains" [40]. The intention is to provide more concrete estimates of FLW. Moreover, the application of the FLI aims to have a standard method at national level for estimating losses occurring at each stage of the food chain that, which, it is assumed, are independent of each other.

In 2019, the first global estimate was published through the use of FLI and accounted for $13.8 \%$ of food produced in 2016 [2] and 14\% of that produced in 2019 [41]. On the other hand, FWI was first estimated in 2019 and accounted for 17\% of total global food production, corresponding to 931 million tonnes of food waste, 11\% in households, 5\% in food service and $2 \%$ in retail [41]. The indexes previously described, however, only take into account quantitative losses. Qualitative losses are difficult to quantify since one would have to compare the optimal value of a product with the one that it acquires as it passes through the FSC, such as the loss of nutritional values during processing [42]. Quantitative loss is also referred to as "physical loss", which includes food removed for aesthetic reasons, but does not include the decrease in mass as a result of processing operations (e.g., drying) [18]. In addition, the FLI considers percentages of food lost and not tonnes since, otherwise, an increase in losses would be attributable to an increase in total production [2].

With regard to commodities, the FLI focuses on the top ten commodities by economic value divided into five groups for each country: (i) cereals and pulses, (ii) fruits and vegetables, (iii) roots, tubers and oil crops, (iv) animal products, and (v) fish and fish products [40]. Roots, tubers and oilseed crops are characterised by the highest losses, mainly affecting cassava and potatoes. Following this, the highest levels of losses are recorded for fruit and vegetables, due to their high perishability [2]. However, the percentage of FLW of different food groups differs in different countries around the world [15]. As an example, estimates made in the United States in more than 200 companies showed that most food losses concern meat, poultry and fish (41\%), vegetables (17\%) and dairy products $(14 \%)$ [43]. In Sweden, Eriksson, et al. [44] found that out of the total fruit and vegetables delivered to different retailers, $4.3 \%$ was wasted, of which 3.01\% was rejected at delivery, $0.99 \%$ was registered waste and $0.3 \%$ was unregistered waste in the retailer. In this way it was seen that correct waste registration can be a winning strategy in reducing waste of fresh fruit and vegetables. 
By use of a questionnaire administered to 47 food processing companies in Belgium, the food losses for the different sectors were analysed concluding that $2.1 \%$ of the total production was lost in general in all companies [14]. In addition, the highest losses occur in the fruit and vegetable sector (4.63\%) while the lowest losses occur in meat one (0.14\%). An FAO report of 2011 [1] showed that annual food losses accounted for $40-50 \%$ for root crops and fruit and vegetables, 30\% for cereals and fish, and 20\% for meat and dairy products (Table 1).

Table 1. Part of the initial production lost or wasted for each commodity group in different regions.

\begin{tabular}{|c|c|c|c|c|c|c|}
\hline & $\begin{array}{c}\text { Roots } \\
\text { and Tubers }\end{array}$ & $\begin{array}{c}\text { Fruits } \\
\text { and Vegetables }\end{array}$ & Cereals & $\begin{array}{c}\text { Fish } \\
\text { and Seafood }\end{array}$ & Meat & $\begin{array}{c}\text { Diary } \\
\text { Products }\end{array}$ \\
\hline Europe & $52 \%$ & $46 \%$ & $34 \%$ & $31 \%$ & $22 \%$ & $12 \%$ \\
\hline $\begin{array}{l}\text { North America } \\
\text { and Oceania }\end{array}$ & $60 \%$ & $52 \%$ & $35 \%$ & $49 \%$ & $23 \%$ & $20 \%$ \\
\hline Industrialised Asia & $48 \%$ & $36 \%$ & $34 \%$ & $36 \%$ & $21 \%$ & $11 \%$ \\
\hline $\begin{array}{l}\text { Sub-Saharan } \\
\text { Africa }\end{array}$ & $45 \%$ & $52 \%$ & $19 \%$ & $33 \%$ & $27 \%$ & $25 \%$ \\
\hline $\begin{array}{l}\text { North Africa, West } \\
\text { and Central Asia }\end{array}$ & $33 \%$ & $56 \%$ & $30 \%$ & $30 \%$ & $23 \%$ & $20 \%$ \\
\hline $\begin{array}{l}\text { South and } \\
\text { Southeast Asia }\end{array}$ & $41 \%$ & $52 \%$ & $20 \%$ & $35 \%$ & $19 \%$ & $22 \%$ \\
\hline Latin America & $39 \%$ & $56 \%$ & $26 \%$ & $29 \%$ & $21 \%$ & $22 \%$ \\
\hline
\end{tabular}

Based on the phases of the FSC, it was found that $24 \%$ of global FLW takes place at the production stage, $24 \%$ during postharvest, and $35 \%$ at consumption, these stages accounting for more than $80 \%$ of global FLW [8].

FLW also depend on the specific conditions and local situation in a given country. In fact, the amount of FLW is comparable in developing and industrialised countries with the difference that in the former it occurs almost exclusively in the first stages of the food chain (30-40\% of food lost), while in developed countries, between $40 \%$ and $50 \%$ of food waste occurs in the retail and consumption stages [45]. Lipinski, Hanson, Lomax, Kitinoja, Waite and Searchinger [8] also reported that developing countries are responsible for $44 \%$ of total FLW, 31\% of which in the first stages, and in particular at growing and harvesting (14\%), post-harvest (15\%) and processing (2\%). On the other hand, developed countries and industrialised Asian nations resulted as responsible for about 56\% of total FLW, with the highest waste at consumption (28\%) [8].

Nevertheless, the amount of food wasted in developed countries (222 million tonnes) is almost equal to the total food production in Sub-Saharan Africa (230 million tonnes) $[1,46]$. Moreover, as food chains in non-industrialised countries are less conventional, it is more difficult to analyse them using standard methods than in high-income countries [13]. However, it is difficult to define the actual effectiveness of prevention and reduction efforts, as well as the impact they have on natural resources, due to the lack of comprehensive data on the amount of food lost and wasted [21].

\section{Measures to Prevent and Reduce Food Loss and Waste Improving Natural Resources Management to Prevent and Reduce Food Loss and Waste}

Preventing or reducing FLW and, consequently, making the best use of natural resources is a major challenge, especially because the world population is estimated to reach almost 10 billion by 2050, which will require an increase of at least $70 \%$ in food production [2,47].

When deciding what action to take to prevent or reduce FLW, in addition to the need to understand why these occur, where they occur and how much they amount to along the entire food chain, it is also important to ask how, where and why strategic actions need to be taken. 
The impact of preventing or reducing FLW is not only limited to the gain to individuals, but also to society at large. In these terms, there are three ways in which reductions in waste can benefit society, which are through:

1. The improvement of food security and/or nutritional status;

2. Reducing the environmental impact in terms of greenhouse gas emissions and pressure on water and land resources;

3. Improving productivity and resulting economic growth.

Therefore, in view also of the increasing demand for food, reducing or preventing the generation of food waste, while limiting the impact on environmental resources, is considered one of the most effective strategies [48].

\subsection{Food Security and Nutrition}

Food security is defined by the FAO (2011b.) as "a situation that exists when all people, at all times, have physical, social and economic access to sufficient, safe and nutritious food that meets their dietary needs and food preferences for an active and healthy life".

The balance of the entire food system is compromised by increasing levels of loss and waste, which also affects food supply, both in terms of quantity and quality, and prices. Reducing these levels of waste would therefore lead to an increase in the availability of food and thus improve food security and nutrition. However, the actual effects can be complex and will depend on the geographical location and where along the food chain the reductions take place [1].

Reducing FLW can, however, also have negative effects. In fact, an increase in availability may lead to lower food prices, which may have a negative impact on supply. It should also be considered that food discarded as unfit for human consumption, even increasing the level of waste produced, improves the quality of food, thus preventing possible diseases that would have a negative impact on food security [2,49]. Reducing FLW can also increase food security in terms of accessibility through, for example, an increase in the supply and consequent increase in the income of those selling more of the commodity. However, this depends on how prices change as a result of waste reductions because if prices fall, the general population will have more access to food, but farmers will see their incomes fall [50].

In order to maintain certain standards of food security and nutrition, it is inevitable that some food will be lost or wasted, resulting in quality losses. This is not only because products that are unfit for human consumption must be removed from the food chain, but also because it is often necessary to overproduce in order to keep the availability of food stable and to ensure that more people have access to healthy and nutritious food, but this also leads to more waste because some of the more nutrient-rich foods have a shorter shelf life [2,51].

Good nutrition also requires a varied diet that includes fruit, vegetables and foods of animal origin that are more perishable. In fact, a study conducted in the United States of America found that higher quality diets are associated with more food waste but also with less environmental impact [52]. However, reducing food quality losses can improve consumers' food consumption.

A study examining the market impact of reducing losses and waste found that a $20 \%$ reduction in food losses in developing countries over 10 years would lead to increased supplies and lower prices, benefiting both industrialised and non-industrialised countries. For example, a decrease in feed costs would see an increase in feed exports or, in other cases, feed imports [53,54].

This is also confirmed by another study which found that a reduction in FLW leads to higher production while using the same inputs. This increases supply from producers, leading to lower prices and increased imports. According to this study, reducing losses and waste in Europe has a positive, even if small, effect over long distances, such as in sub-Saharan Africa [55]. Halving food losses, according to a study of 2020 by the Global Panel on Agriculture and Food System for Nutrition [56], would increase nutrient intake 
and also have a positive impact on chronic diseases such as heart disease and type 2 diabetes. FLW also imply micronutrient losses, as shown by an FAO study, according to which reducing food losses could contribute to a better nutritional status of children under 5 years of age as a result of an increased intake of micronutrients, such as vitamin $\mathrm{A}$, in the diet [42].

FLW can have both negative and positive effects on food safety and nutrition because even if it is necessary to discard food that is unfit for human consumption, it still falls under the scope of food waste. Furthermore, in order to prevent crops from being attacked by pathogens, farmers use chemicals that may be of greater concern to the end consumer [2,57].

\subsection{Environmental Sustainability}

Reducing FLW is enshrined in Sustainable Development Goal 12 (SDG 12) on sustainable consumption and production, in particular target 12.3, which calls for halving food waste and reducing food losses by $2030[40,58,59]$. The inclusion of FLW reduction in the SDG target reflects the fact that producing food that is not consumed, whether lost during production or wasted at the table, not only reduces the amount of food available, but also constitutes a substantial waste of economic and environmental resources [60]. In a context where demand for food is estimated to increase by almost half by 2050 as a result of the growing population, it will be increasingly difficult to meet sustainable development goals, particularly from an environmental perspective in terms of the use of natural resources (water and land) and the production of greenhouse gas (GHG) emissions. Therefore, reducing FLW is an important strategy to consider in improving the use of environmental resources It is estimated that preventing food losses can reduce GHG emissions by $8 \%$ and water use by a quarter [61].

Each food product can have a different impact on natural resources and three types of indicators-footprints-need to be considered, which are generally quantifiable:

i Carbon footprint

The carbon footprint of food is the total amount of GHG that is emitted during the entire life cycle of food, expressed in carbon dioxide equivalent $\left(\mathrm{CO}_{2}\right)$. This quantity includes all GHG emitted during production, transport, processing, distribution and consumption, as well as emissions caused by waste disposal [62]. In fact, a study based on EUROSTAT data estimated that, considering the entire life cycle of a product, in one year food waste was responsible for the production of approximately 170 million tonnes of $\mathrm{CO}_{2}$ equivalent in the European Union [43]. The largest GHG emissions occur in the primary production stages and accumulate until the food reaches the end of its life cycle, depending on the type of food product and the food production system in a given country [63].

\section{ii Land footprint}

Land use has a major influence on climate change, biodiversity and the ecosystem. Although there is no standard method for quantitatively assessing the actual land footprint, according to the FAO [2] it can be defined as the area required to produce a given food. Consequently, the initial stages of the FSC are those that have the greatest impact on land use, which, as in the case of the carbon footprint, depends on the type of food and the production system [62].

\section{iii Water footprint}

The water footprint represents the amount of freshwater required to produce a food and also depends on the type of product and stage in the food chain, with greater use in primary production stages $[64,65]$.

Based on FAO data published in 2011 and 2013, it is estimated that FLW are responsible for:

- The emission of 3.3 giga tonnes of carbon dioxide equivalent;

- The consumption of $250 \mathrm{~km}^{3}$ of water;

- The use of almost 1.4 billion hectares of land [60]. 
Springmann, et al. [48] assessed the impact that different food loss prevention strategies can have on environmental resource use both if food waste were halved and if it were reduced by $75 \%$. Specifically, halving FLW by 2050 would reduce natural resource use by $6-16 \%$ and $9-24 \%$ if food losses were reduced by $75 \%$, compared to the $50-92 \%$ increase in environmental impacts that would occur if no preventive or reduction action were implemented.

According to the FAO [2] there is significant potential to improve environmental sustainability by reducing FLW. However, it is not a given that there is only a positive impact as further possible consequences should be considered. For example, with a reduction in food losses, there will be the same amount of resources used by producers but the amount of goods produced will be greater. However, increased production may have a negative impact on the environment by increasing GHG emissions [66].

When applying interventions to reduce FLW, it is important to define the target towards which one is aiming as carbon, soil and water footprints are affected differently by food loss or waste depending on the type of food product, how it is produced and the stage in the food chain at which these losses occur. In fact, food lost at the primary production stages has a less relevant impact in ecological terms than the same food wasted at the final stages of the food chain, household level for example [67].

Land and water footprints are most concentrated at the primary production stage, although significant amounts of water may be used during processing, while GHG emissions can occur and accumulate throughout the supply chain, although they are greatest towards the retail and consumption stages. Indeed, efforts should be more focused on reducing consumer waste $[2,61,65]$.

The size of the impact on different natural resources depends on the type of product. Meat and animal products, for example, do not contribute much to total levels of FLW, but have a large impact on the land footprint (more than 50\%). In contrast, their contribution to water consumption is very small compared to cereals and pulses, which account for almost $90 \%$ of the water footprint because they are water-intensive crops. These crops also contribute more to GHG emissions than the other food groups, followed by root, tuber and oil crops $[60,65]$.

The impact a given product has on the use of environmental resources also differs according to geographical location. In fact, according to the FAO [60], Central and South Asia are among the largest contributors to the water footprint caused by food waste production, mainly due to the high use of cereals, which are the crop most responsible for the ecological footprint of FLW. However, these data do not take into account the different production systems used in different countries around the world. For example, in maize production carbon, water and land footprints differ between countries [68]. In Southeast Asia and South America, GHG emissions are higher, and in West Africa, the land footprint is larger than in Europe, which has a larger water footprint [2].

The actions needed to reduce the environmental impact of FLW could also vary according to the level of the FSC in which they are implemented. As GHG emissions accumulate along the FSC, they will be greatest at the final retail or household stages. In contrast, water and land footprints are more pronounced at the primary production stages [60].

\subsection{Economic Development}

The economic impact resulting from the production of food waste can be related to the cost of production, which depends on the resources used to produce the good, and to the market price of the goods, which is linked to the utility of the product [11]. To this can be added an assessment based on the theory of welfare economics, which looks at FLW as an impact on society as a whole. In fact, according to the FAO (2019b), a distinction must be made between the benefits to individual actors in the FSC, "The business case", and those to society as a whole, "The economic case" [69]. 
Both producers and consumers can benefit from the reduction of FLW as producers with the same amount of resources can sell more and at the same time have less goods to dispose of, thus reducing disposal costs. In addition, market prices can decrease resulting in a gain for consumers who will be able to buy cheaper food products [2,70]. However, there are hurdles as often certain levels of FLW are unavoidable even in a situation where the benefits obtained from preventive strategies do not outweigh the costs incurred in implementing them. In addition, both producers and consumers are not fully aware of the quantities of waste produced and the consequences that these may have, so they are not always able to take sensible action to obtain real benefits for themselves [71,72]. Producers are often uncertain about the actual benefits of adopting recommended practices [73, 74]. Chegere [74] analysed the role of post-harvest practices in reducing food losses in 420 maize-producing households, and the cost-benefit analysis showed that in some practices the costs outweigh the benefits. Therefore, it is important to identify the crucial points for the implementation of reduction strategies to ensure economic benefits as well.

For companies, investing in reducing FLW can have a strong economic return. In fact, a study conducted by the World Resources Institute (WRI) and the Waste and Resources Action Programme (WRAP), a non-profit company founded in 2001 and operating in England, Scotland, Wales and Northern Ireland, analysing different types of companies in 17 different countries, found that over $99 \%$ of sites achieved a positive return on their investment in food loss reduction and that the median benefit-cost ratio was 14:1. Thus, half of the commercial sites for every USD 1 (or other currency) invested in FLW reduction had a return of USD 14 [45]. Moreover, in another analyses carried out by WRAP [75], based on FAO studies from 2011, it was found that in both South and Southeast Asia and industrial Asia cost benefits could be achieved as a result of a $20 \%$ reduction in food waste, especially for fruit and vegetables and cereals. A study by Rethink Food Waste (ReFED), in calculating The Business Profit Potential in the United States of America, also found that applying prevention strategies can potentially increase companies' profits by USD 1.9 billion per year [76]. Therefore, a company's earnings can increase with a reduction in food loss levels as producers can thereby increase supply. However, this may induce a decrease in prices and thus hinder actual profits $[2,8]$.

Consumers gain both from the fact that reducing waste means spending less money, but also from the fact that they get cheaper food if producers increase supply. This, however, leads consumers to be less careful about food waste [2].

In non-industrialised countries, almost all the food lost comes from the initial stages of the food chain. In fact, Rutten and Kavallari [55] showed that in North Africa and the Near East the implementation of strategies to reduce food losses led to an increased supply by farmers and a consequent decrease in prices for consumers. On the contrary, in industrialised countries, waste occurs at the last stages of the food chain, so it is important to prioritise consumer awareness of this issue so that consumers waste less food [77]. The result would be an increase in income for households, which might induce them to spend the money saved on a higher quality food product or to buy another food in larger quantities. According to WRAP [75] there is no decrease in income from sales even if consumers waste less, because they probably tend to buy more expensive food. Thus, decisions about the most effective actions to be taken in preventing and reducing FLW must consider not only the costs involved, but also the benefits to the community as a whole and to individual private actors [61].

\subsection{Possible Strategic Actions at Different Levels of the Food Chain}

The most recent estimates in Europe, reveal that the majority of food waste comes from households, food services and retailers contributing $70 \%$ to waste generation, while production and processing stages account for the remaining 30\% of the total [22].

Growing interest in the environmental and economic damage caused by food waste has led to an increased political and public consensus on the need to address this challenge, as demonstrated by the amended Waste Framework Directive (2018/851/EC), which 
obliges EU Member States to monitor food waste generation and take measures to limit it, placing food waste prevention at the top of the waste hierarchy, as illustrated in Figure 2 (UNEP, 2014). This is also demonstrated by the inclusion of food waste reduction in the "Farm to Fork Strategy" by the European Commission as part of the European Green Deal, which aims to make food systems "fair, healthy and environmentally friendly" [78]. It is therefore important, according to the European Commission, to "redesign food systems that today are responsible for almost one third of global GHG emissions, consumption of large amounts of natural resources, loss of biodiversity and have negative health impacts (due to both under- and over-nutrition) and do not allow for a fair economic returns and livelihoods for all actors, especially primary producers". Evaluating preventive actions is essential to understand the real benefits they can bring. There are, therefore, criteria that are important to follow according to the European Commission:

- Effectiveness: considers the success or otherwise of an intervention;

- Efficiency: assesses the relationship between what is needed to implement a preventive action and the changes that follow;

- Relevance: considers the link between the objective to be achieved and the needs of society as a whole;

- Coherence: assesses whether the intervention follows a logic in relation to other interventions;

- $\quad$ EU-added value: is a sum of all other criteria [79].

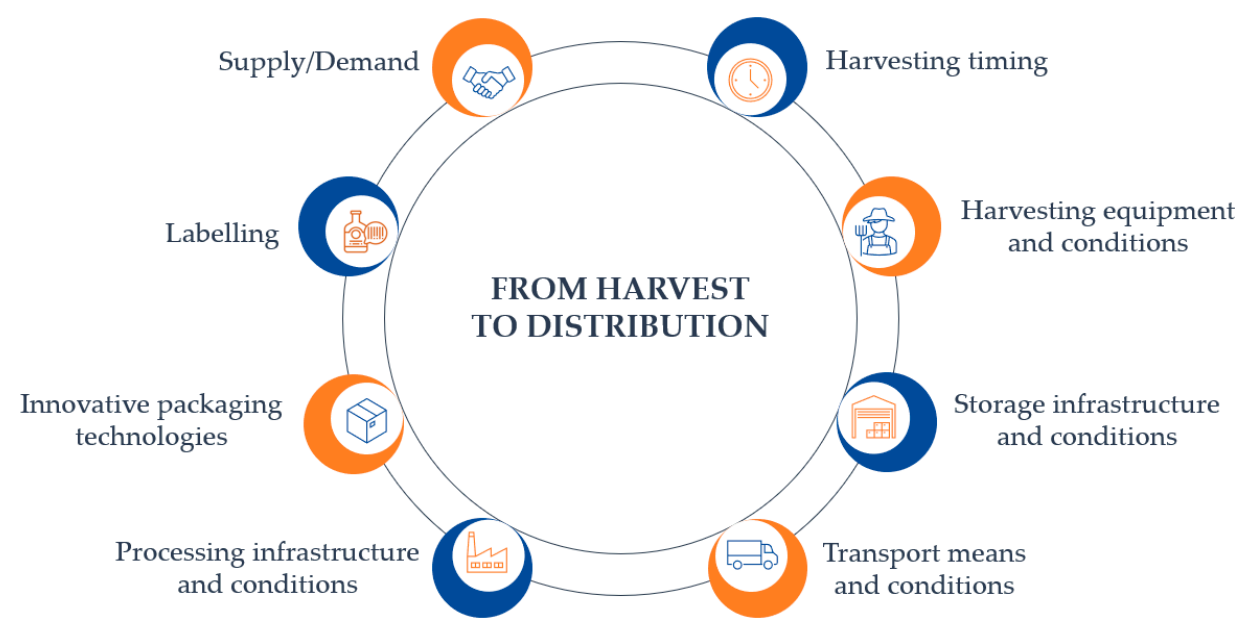

Figure 2. Measures to prevent and reduce FLW from harvest to distribution stages.

All actors in the food chain, from production to consumption, must take action against FLW. Therefore, different authorities and institutions have implemented awareness-raising campaigns on this issue (Figure 2).

\subsubsection{Preventing or Reducing Food Loss and Waste at Harvest and Production}

Losses during the harvesting phase have several causes, including timing, techniques, equipment and harvesting conditions. At this stage, products not intended for sale for human consumption are used for non-food purposes such as bioenergy production or soil improvement, or animal feed production. Nevertheless, it is necessary to optimise the use of production resources to address food losses at farm level [22].

Fresh products such as fruit and vegetables, but also animal products, can spoil easily in hot climates and especially in developing countries due to a lack of water or adequate storage and transport infrastructure. However, several new technologies have been devised to increase the life of products during storage, such as solar dryers or a rice storage bag that blocks the flow of both oxygen and water vapor, limiting post-harvest losses of this cereal by up to $15 \%$, as well as the loss of nutritional quality [60]. Developed by the International Rice Research Institute (IRRI), the "Super bag" is a storage bag that can be used to store 
grains and other crops (e.g., coffee) safely for extended periods. The bag can approximately double the germination life of seeds, control insects without using chemicals and improve the rice overhead recovery of stored grain by about 10\% [80].

Another example is the sweet potato, which is very susceptible to rot due to its high water content. Therefore, in countries with poor infrastructure, a large part of the harvest $(79 \%)$ is lost compared to industrialised countries where, under optimal conditions, potatoes can be stored for up to a year. However, improved storage conditions or the adoption of special techniques can increase the shelf life of potatoes and improve the yield by up to $48 \%$ [81]. Sequential harvesting, according to a study conducted in South Africa, has also resulted in $8 \%$ less potato crop losses in developing countries. In fact, it has been seen that in these countries leaving crops in the ground for longer periods after maturity and harvesting them sequentially can lead to lower levels of loss than traditional harvesting methods [82]. In developing countries, food losses are also attributable to the processing stage due to a lack of adequate processing facilities. This, according to the FAO [1], is one of the reasons why industries in these countries are unable to meet the demand for food, a problem also linked to the seasonality of production. Excess production or unforeseeable machinery problems can also cause losses during the processing of a product [83].

According to the latest estimates, about $19 \%$ of the total food waste generated in the European Union comes from the processing sector [39]. Prevention and reduction of food losses in this sector can be based on improved awareness of proper processing techniques, offering different sizes of packaging to meet different consumer needs and innovative packaging solutions, improving use-by date marking, and using food that cannot be intended for human consumption for feed or non-food uses [22].

Successful action in preventing food losses can be based on the implementation of a new packaging technology that improves the quality, freshness and safety of food or ensures a longer shelf life. Tesco, the UK's leading supermarket chain, has been experimenting with revolutionary packaging: the packaging contains a strip coated with a natural product that absorbs ethylene, the hormone that ripens fruit. Initial trials have been a success and suggest that the device could be used on a wide range of fruit and vegetables at no extra cost to shoppers. The packaging has been tested with tomatoes and avocados, which are among the products that account for the largest losses in the food industry [84].

Not only the quality, but also the size of packaging can cause significant losses. Therefore, offering a range of products in various packaging sizes to suit different lifestyles and household needs can help prevent waste at consumer level. With this in mind, the Midlands Co-operative, a consumer co-operative in the UK, and Fyffes, a fresh produce company, worked in partnership to prevent banana waste. The partnership showed that introducing small $12 \mathrm{~kg}$ boxes of bananas in eight convenience stores would reduce waste by $90 \%$ and $\mathrm{CO}_{2}$ emissions by 56 tonnes per year. This solution was created because it was found that the $18 \mathrm{~kg}$ boxes were too big for the convenience stores. The smaller boxes had the additional advantage of maintaining product quality for the consumer. In addition, more frequent replenishment meant that the fruit was fresher and less bruised, which resulted in additional sales as consumers could benefit from a better quality product and less food was wasted in the store [85].

The transport phase is also a crucial point for food losses, so improvements in transport means and conditions, as well as a reduction in distances between production and sale, could reduce loss levels. At the same time, however, the environmental impact must be taken into account as frequent and small deliveries can optimise efficiency within a facility, but at the same time increase the overall carbon footprint [86]. When possible, creating shorter food chains can have the best economic and environmental impact, while also improving food security $[60,87]$.

Often there is miscommunication between the different parts of the FSC, resulting in a lack of balance between supply and demand. This can lead to major food losses as farmers may find themselves with surplus produce if supermarkets suddenly reduce orders. It is 
therefore important that producers and buyers are in constant communication with each other $[1,67]$.

\subsubsection{Preventing and Reducing Food Loss and Waste at Retail}

About $5 \%$ of the total amount of food waste in the European Union is generated in the wholesale and retail sector (about 5 million tonnes) [39].

Especially in developing countries, markets are not adequate for the sale of food, as they are often overcrowded and lack proper hygienic conditions and cooling equipment. They are therefore a major source of food waste that could be reduced, for example, by simply adding a roof to protect food from sun and rain [88]. In developed countries, on the other hand, the culture of abandonment means that large quantities of goods are displayed and remain unsold because they are close to their expiry date. The analysis carried out by Gunders [83] showed that retailers who tried to offer "best before" items at a discounted price reported that this did not reduce sales but rather increased customer satisfaction.

Moreover, throwing away unsold products might be economically advantageous, but not when considering the social and environmental impact [88]. For this reason, some companies have implemented some strategies that have also led to increased profits in selling products close to their expiry date, such as selling these products at discounted prices or using them to offer ready-made meals. An example is the popular Californian grocery shop, Berkeley Bowl, which has estimated to sell USD 1500 of products per day in this way and also offers bags of damaged or almost expired products at a discounted price [83]. Measures to reduce in-store waste have also been taken at an independently owned shop in London. In fact, the owner, Thornton's Budgens, has made it possible for its shop to buy ready-made food cooked with ingredients from the shop itself close to its sell-by date. In addition, products that are no longer saleable but are still edible are donated to "Food Cycle", a charity that provides ready-made food to local communities [89]. The shop also hosts "Food from the Sky", a community project that grows organic fruits and vegetables on the roof which are then sold in the shop. Non-edible food waste from the shop is used to make compost for the garden providing zero food miles [90].

Retail owners take voluntary initiatives to reduce or prevent waste. For example, the Sainsbury's and Tesco chains have introduced "Buy one, get one later" (BOGOL) campaigns to reduce food waste and save customers money. They have adopted a staggered purchasing mechanism to avoid over-buying with the classic "buy two, get one free" offers that are one of the biggest causes of household waste. With this mechanism, customers can buy and collect a second identical product for free after the first purchase, rather than having to buy both at the same time [11].

Retailers are also committed to promoting the reduction of food waste through a variety of actions, including extensive educational campaigns or the redistribution of unsold products to charities [22] (Figure 3).

\subsubsection{Preventing or Reducing Food Loss and Waste at Consumption}

Across Europe, it is estimated that over $50 \%$ of food waste (47 million tonnes) comes from households [39]. The last stages of the food chain, especially at consumer level and in developed countries, account for most of the total food waste. This may be due to increased urbanisation, a lack of awareness of the cost and resources used in food production, or retail methods that often lead consumers to buy more food than they need (e.g., "two for one" offers) [91]. A cultural change is therefore needed. Consumers need to become more aware of the amount of waste they produce and in this respect the help of consumer organisations can be crucial in providing recommendations and practical advice to reduce food waste at home through awareness-raising campaigns [22] (Figure 4a). 


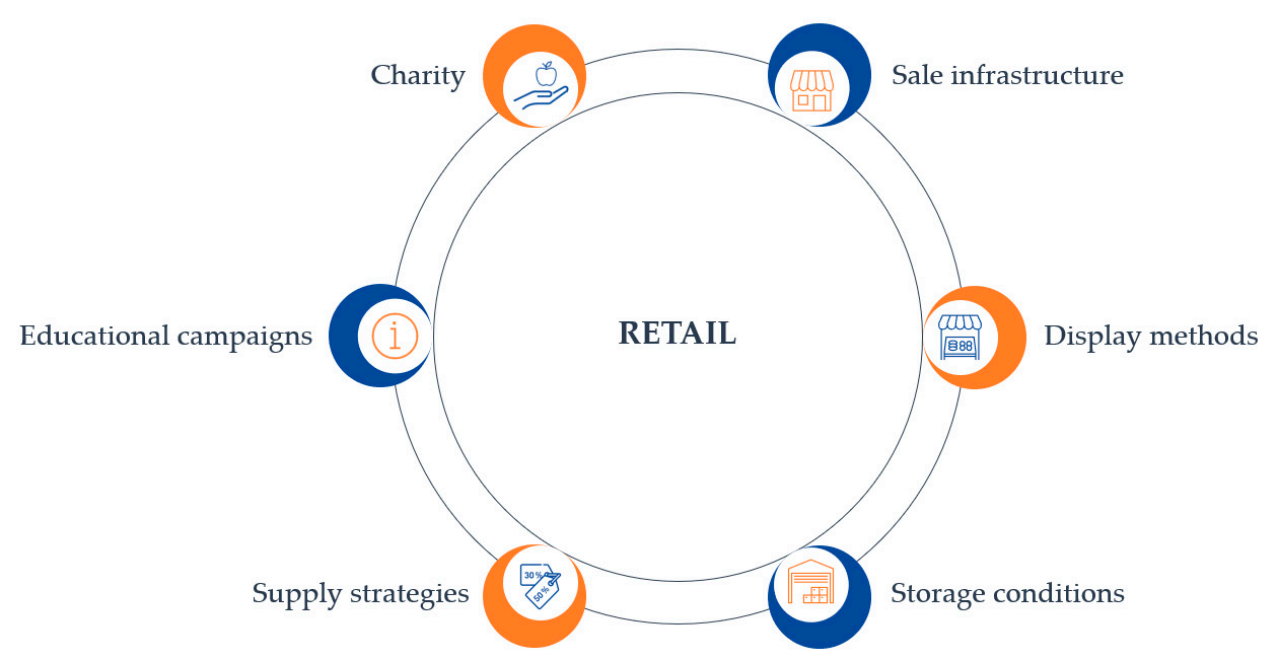

Figure 3. Measures to prevent and reduce FLW at retail stage.

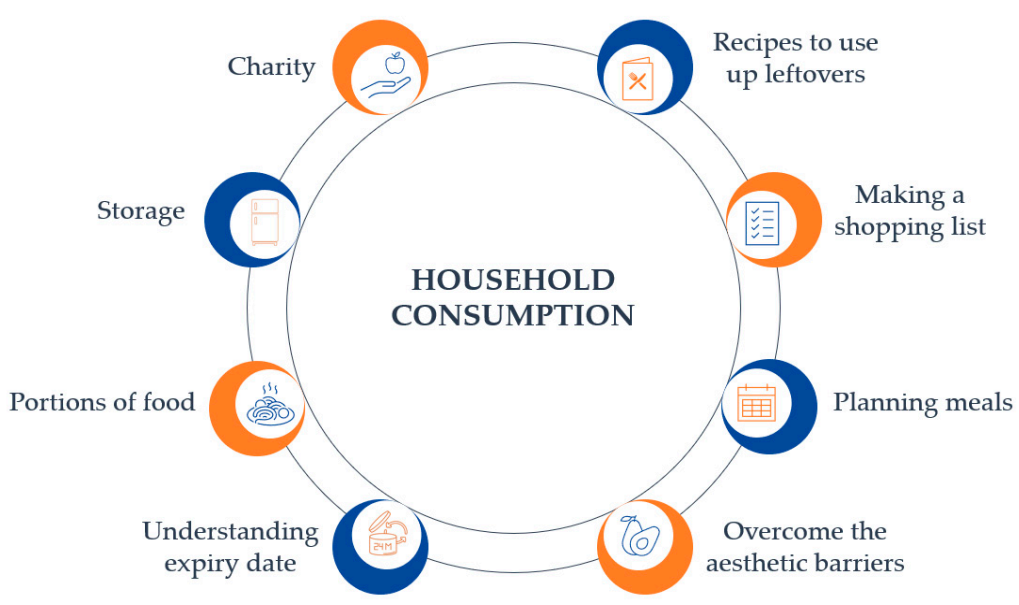

(a)

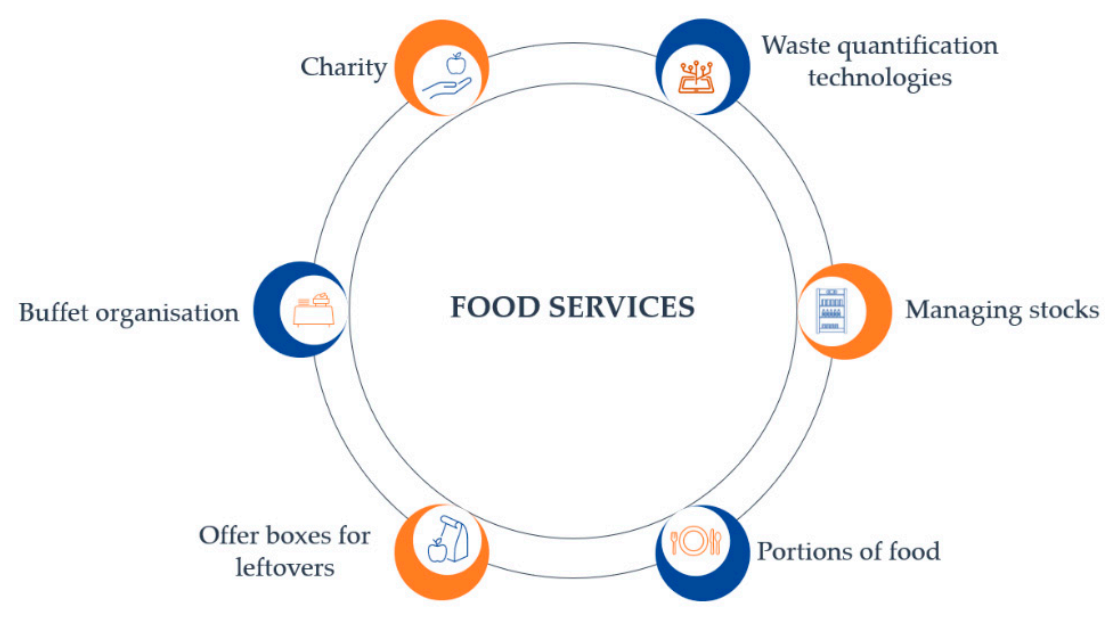

(b)

Figure 4. Measures to prevent and reduce FLW at (a) household consumption and (b) food services.

For example, key messages could be about saving families money, and one tool could be recipes to use up leftovers or forgotten food, or portion size guides to help 
people cook the right amount of food, such as the Italian project "Chef Save the Food" run by three consumer associations. The aim is to teach families how to avoid wasting food through a cooking show in which professional chefs have to create a meal with the leftovers found in people's kitchens: in this way they try to raise awareness about the value of food and therefore to avoid waste in order to protect the environment and the territory [79]. Other guidelines can provide advice such as making a shopping list and planning meals, information on how to store different foods in the home to keep them at their best, information on what could be frozen to be eaten later, etc. [92]. It is on these principles that WRAP launched the "Love Food, Hate Waste" campaign in 2007, which aims to raise awareness among citizens and companies about reducing food waste by offering useful tips and advice, for example, on how to prepare the right portions or store food in the fridge, freezer or pantry, as well as practical recipes on how to reuse leftover food [11].

A further example is the "Save Food Cut Waste" campaign in Singapore launched in 2012 with the main objective of raising public awareness. Through the website www. savefoodcutwaste.com (accessed on 29 April 2021), information is also provided on the environmental and social impact of food waste and local solutions on how to reduce, redistribute and recycle food waste [41].

The European Commission has also compiled a list providing an overview of possible tips to reduce food waste at home when buying and consuming food such as: writing a list to plan meals for a week by checking the ingredients in the fridge and cupboards; buying "ugly" fruit and vegetables that are still good to eat to overcome the aesthetic barriers that lead to a large production of food waste; checking the temperature of the fridge as food should be stored between 1 and $5{ }^{\circ} \mathrm{C}$ for maximum freshness and longevity; turning ripening fruit into smoothies or fruitcakes, or vegetables that are starting to wilt into soup; serving small quantities of food and buying fruit and vegetables in bulk rather than prepackaged to buy exactly the amount needed; learning to distinguish expiry dates [22]. A better understanding of the date on food products, "use by", related to safety, and "best before", related to quality, by all stakeholders, can prevent and reduce food waste. In this regard, a dedicated subgroup of the EU Platform on FLW was set up to discuss possible options involving all stakeholders. These include visual guides for proper understanding, including actions to improve readability; promotion campaigns towards consumers for better learning the meaning of different dates thus helping them to understand that " best before" is not an expiry date after which the food should not be consumed (such as the campaign launched by the Nordic Council of Ministers, shown in Figure 4); improving format, presentation and terminology to facilitate consumer understanding [93].

The UNEP, WRAP, FAO and the SAVE FOOD initiatives have launched the "Think.Eat.Save" campaign in support of the UN Secretary-General's "Zero Hunger Challenge" to provide a global vision to reduce food waste and accelerate action. The campaign draws attention to the serious problems arising from the high volume of perfectly edible products that are wasted [94].

According to the latest estimates, the food service sphere accounted for $12 \%$ of the total food waste in the European Union (11 million tonnes) [95].

Since 2013, Compass Group UK \& Ireland, an industry provider of catering, cleaning, distribution and facilities management services to a range of clients and sectors in England, Scotland, Wales and Ireland, has been working with Winnow, a specialist food waste measurement company with the aim of reducing the amount of food wasted. Winnow has developed a smart measuring container, which measures the type, volume and value of food waste. Kitchens are provided with a touchscreen tablet to identify what is thrown away and then an electronic scale records the weight. Each morning chefs and managers receive a report showing where food waste has occurred and the estimated cost to help quantify what is being thrown away so that there is greater awareness of where and how to take action to reduce potential waste [96]. 
In France, the Union Nationale des CPIE (Centres Permanents d'Initiatives pour l'Environnement), a collection of associations aiming to undertake environmental initiatives, acts at national and regional level to significantly transform practices for more responsible and sustainable mass catering. To this end, it has drawn up a guide that provides advice on how to conduct a food waste reduction programme, including identifying priority actions, managing stocks, motivating staff and raising customer awareness on this issue [97].

Large amounts of food waste are produced at the level of food services and many are implementing strategies to reduce food waste. Clients are served standard sized meals that are often too large for the individual's needs, so one strategy could be to reduce portion sizes or offer boxes for leftovers. To avoid over-consumption again, services could offer only what is still available close to closing time or cook only on request [22].

In hotels, buffets are the biggest cause of waste due to the display of large quantities of food. So, winning strategies in reducing waste could be offering higher value products à la carte, or offering single portions rather than trays of food, or even selling leftovers from the buffet later [98] (Figure 4b).

\subsubsection{Legislation to Prevent and Reduce Food Loss and Waste}

Policy actions need to be based on a holistic approach that involves all parts of the food chain in order to increase cooperation and awareness of different actors. Thus, legislators can put in place different measures, more or less stringent, such as simple recommendations or guidelines or more restrictive regulations and laws. Governments can also act through public investment in infrastructure, offering guidelines on proper harvesting and postharvesting methods to make them as sustainable as possible, setting limits on the use of chemicals by implementing sanitation protocols, etc. [6] (Figure 5).

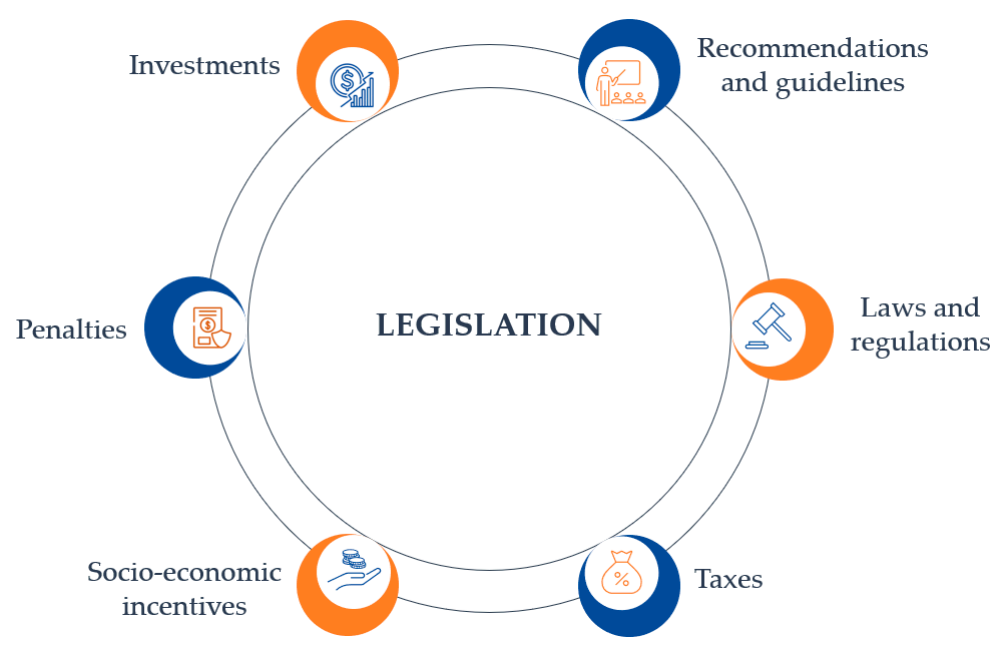

Figure 5. Measures to prevent and reduce FLW at legislative level.

Numerous strategies and cooperation between different parts of the FSC are certainly crucial in the fight against food waste, but stakeholders will be more encouraged to act if the actions to be taken are cost-effective or if they are obliged to comply with restrictive regulations such as the obligation to periodically report on waste produced on the farm or the imposition of waste taxes [99].

Some governments have moved in this direction, setting targets to reduce food waste and committing to improving the sustainability of the food chain, reducing dependence on natural resources and changing consumption patterns. For example, in Italy in 2016, law no. 166 of 19 August 2016 on "Dispositions concerning the donation and distribution of food and pharmaceutical products for social solidarity purposes and for the limitation of waste" was approved (GU Serie Generale no. 202 of 30-08-2016). Following the implementation of this law, better known as the Gadda Law, the association "Io Potentino Onlus", in 
collaboration with the Basilisca Brewery of Potenza, produced a beer, the "LA166", using surplus bread recovered during their daily activities to fight food waste [100].

Further examples of the ways in which policy and legislation can be used to support food waste prevention are illustrated by the FUSIONS project. It suggests several sets of recommendations to support the development and implementation of a common European policy framework on food loss and food waste prevention. These include the need for a common definition of food waste and the development of a standardised methodology for its measurement and data collection, encouraging dialogue between Member States and stakeholders in the FSC, stimulating social innovation for food waste prevention through guidelines advising on how to secure sources of funding, encouraging donation by promoting awareness raising among all parties, etc. [95]. These measures will therefore include communication campaigns, educational programmes aimed at schools, training programmes for food business operators, prevention guidelines, etc. For example, the government of Abu Dhabi has expressed its commitment to improving waste management throughout the Emirates with the creation of Tadweer-The Center of Waste ManagementAbu Dhabi. Established in December 2008, the Centre is the lead agency responsible for monitoring and coordinating waste management activities in the UAE. Following the launch of the Environment Agency's "Think Before You Waste" campaign during Ramadan, meals were donated to people in need with the support of various authorities. One of them, the General Authority of Islamic Affairs and Endowment (Awqaf), during this campaign, communicated important advice and information on food waste to all Imams in the Emirates for dissemination to the community during the prayer service during the Holy Month of Ramadan. Islamic preachers urged residents to consider reducing personal food waste as part of their religious responsibility [101].

The FUSIONS project also identified a number of market-based, price-based strategies for food waste prevention in the policy field. These interventions can include both positive incentives that encourage action by different parts of the FSC such as subsidies to companies for loss reduction technologies, and negative incentives such as the introduction of costs or taxes for waste disposal [95].

Often companies overproduce to prevent demand from exceeding supply. However, this overproduction leads to wastage of more than $50 \%$ of the total production, although a part is still considered unavoidable (5-7\%). This waste typically occurs when a supermarket makes what is known as a "forecast order" for a certain quantity of a product. However, sometimes the supermarket decreases the order and the producer is then left with a large quantity of goods that he cannot sell. Since this type of wastage occurs with finished products, all the energy and resources used to produce them are lost, making it even more wasteful [88]. This example highlights how collaboration and communication between different parts of the food chain is crucial and how equally important is the role of policy makers in balancing these relationships.

Every retail business can deal with waste within its own organisation, but there is a danger of moving waste from one area of the food chain to another. So, collaborations between different retail partners have shown that there are opportunities to prevent waste. Marks\&Spencer (M\&S) and Uniq, one of its key suppliers, worked together to assess the main areas of food waste, concluding that it was necessary to revise the order plan, initially based on previous days' sales, in order to make more accurate future estimates, which are important to avoid wasting large amounts of food. By acting together, both M\&S and Uniq saw a substantial reduction in food waste and, consequently, its costs, and significant environmental gains were achieved [88,102].

\subsubsection{Redistribution of Food}

According to the food waste hierarchy, priority should be given to prevention, and so action should be taken upstream by avoiding excess production of food. Where food surpluses cannot be avoided, it is important to give priority to redistribution for human consumption through initiatives to recover food that is not sold but still edible. By donating 
food, in fact, it is not only possible to act against food poverty, but also to avoid excess food being used for industrial purposes or disposed of in landfills [22].

Redistribution actions are mostly implemented at the distribution and retail stages and have made it possible to avoid the formation of food waste also helped by the collaboration between stakeholders and low operational costs [79].

There are numerous organizations around the world that, through donations from companies, food services or retailers, collect food that would otherwise be lost and distribute it to facilities dedicated to helping the poor [11]. An example is the "Buon Fine Coop" initiative which, since 1990, has aimed at reducing food surpluses from Coop supermarkets by donating them to social voluntary associations, such as the "Fondazione Banco Alimentare Onlus", which then donate them as ingredients or use them to prepare meals to support people in need. All redistributed goods maintain their nutritional qualities and are safe to eat, but are withdrawn from supermarket shelves because they no longer meet quality standards or are close to their expiry date [79].

Therefore, where food surpluses cannot be avoided, it is important to prioritise the redistribution of food for human consumption before it is used for feed or other nonfood uses.

\section{Conclusions}

Interest in implementing strategies to prevent and reduce FLW is increasing. It is important that such actions are based on detailed information on where along the food chain, for which foods and in which countries the greatest losses occur, and the extent and root causes of the problem. All of this can guide different actors, including policy-makers, to implement effective food waste reduction and prevention interventions so that they benefit society as a whole.

However, the lack of data and standard methods to assess the actual effectiveness of different interventions is an obstacle to the identification of best preventive practices. Therefore, many ongoing efforts are aimed at filling this gap, which would help support those working to prevent and reduce FLW around the world by providing guidance on the most effective interventions to be adopted to address this challenge.

Author Contributions: Conceptualisation, R.N. and P.C.; data curation, R.N. and P.C.; writingoriginal draft preparation, R.N. and P.C.; writing-review and editing, R.N. and P.C.; visualisation, R.N. and P.C.; supervision, R.N. and P.C.; funding acquisition, P.C. All authors have read and agreed to the published version of the manuscript.

Funding: This work was supported by Università degli Studi della Campania Luigi Vanvitelli (grant number VALERE: VAnviteLli pEr la RicErca).

Institutional Review Board Statement: Not applicable.

Informed Consent Statement: Not applicable.

Data Availability Statement: Not applicable.

Conflicts of Interest: The authors declare no conflict of interest.

\section{References}

1. FAO. Global Food Losses and Food Waste. Extent, Causes and Prevention; Food and Agriculture Organization of the United Nations: Rome, Italy, 2011. Available online: http:/ / www.fao.org/3/a-i2697e.pdf (accessed on 24 April 2021).

2. FAO. The State of Food and Agriculture-Moving forward on Food Loss and Waste Reduction; Food and Agriculture Organization of the United Nations: Rome, Italy, 2019. Available online: http:/ / www.fao.org/3/ca6030en/ca6030en.pdf (accessed on 24 April 2021).

3. Luo, N.; Olsen, T.L.; Liu, Y. A Conceptual Framework to Analyze Food Loss and Waste within Food Supply Chains: An Operations Management Perspective. Sustainability 2021, 13, 927. [CrossRef]

4. Global Strategy, Improving Methods for Estimating Post-Harvest Losses. A Review of Methods for Estimating Grain Post-Harvest Losses. Working Paper n.2. 2015. Available online: http://gsars.org/wp-content/uploads/2015/09/WP-Review-of-Methods_ for_estimating_grain-loss-160915.pdf (accessed on 24 April 2021).

5. Sheahan, M.; Barrett, C.B. Review: Food loss and waste in Sub-Saharan Africa. Food Policy 2017, 70, 1-12. [CrossRef] 
6. HLPE. Food Losses and Waste in the Context of Sustainable Food Systems; A Report by the High Level Panel of Experts on Food Security and Nutrition of the Committee on World Food Security; HLPE: Rome, Italy, 2014. Available online: http:/ /www.fao. org/3/i3901e/i3901e.pdf (accessed on 24 April 2021).

7. Bricas, N. Urbanization Issues Affecting Food System Sustainability. In Designing Urban Food Policies. Urban Agriculture; Brand, C., Ed.; Springer: Cham, Switzerland, 2019. [CrossRef]

8. Lipinski, B.; Hanson, C.; Lomax, J.; Kitinoja, L.; Waite, R.; Searchinger, T. Reducing Food Loss and Waste: Working Paper; World Resources Institute: Washington, DC, USA, 2013. Available online: https://www.wri.org/research/reducing-food-loss-andwaste (accessed on 24 April 2021).

9. Parfitt, J.; Barthel, M.; Macnaughton, S. Food waste within food supply chains: Quantification and potential for change to 2050. Philos. Trans. R. Soc. B Biol. Sci. 2010, 365, 3065-3081. [CrossRef] [PubMed]

10. Van Gogh, B.; Boerrigter, H.; Noordam, M.; Ruben, R.; Timmermans, T. Post-Harvest Loss Reduction: A Value Chain Perspective on the Role of Post-Harvest Management in Attaining Economically and Environmentally Sustainable Food Chains; Wageningen Food \& Biobased Research report; No. 1751; Wageningen Food \& Biobased Research: Wageningen, The Netherlands, 2017. [CrossRef]

11. BCFN, Food Waste: Causes, Impact and Proposals. Barilla Center for Food \& Nutrition. People, Environment, Science, Economy. 2012. Available online: https://www.barillacfn.com/m/publications/food-waste-causes-impact-proposals.pdf (accessed on 24 April 2021).

12. Reardon, T.; Timmer, C.P.; Barrett, C.B.; Berdegué, J. The Rise of Supermarkets in Africa, Asia, and Latin America. Am. J. Agric. Econ. 2003, 85, 1140-1146. [CrossRef]

13. Centre for Non-Traditional Security Studies, Mind the Gap: Reducing Waste and Losses in the Food Supply Chain. NTS Insight. 2011. Available online: https:/ / www.rsis.edu.sg/wp-content/uploads/2014/07/NL110630_NTS_Insight_30Jun1.pdf (accessed on 24 April 2021).

14. Dora, M.; Wesana, J.; Gellynck, X.; Seth, N.; Dey, B.; De Steur, H. Importance of sustainable operations in food loss: Evidence from the Belgian food processing industry. Ann. Oper. Res. 2020, 290, 47-72. [CrossRef]

15. COMCEC. Reducing On-Farm Food Losses in the OIC Member Countries; Standing Commitee for Economic and Commercial Cooperation of the Organization of Islamic Cooperation: Ankara, Turkey, 2016. Available online: https://sbb.gov.tr/wp-content/ uploads/2018/11/Reducing_On-Farm_Food_Losses_in_the_OIC_Member_Countires.pdf (accessed on 24 April 2021).

16. European Commission. Commission Regulation of the European Parliament and of the Council of 28 January 2002 Laying down the General Principles and Requirements of Food Law, Establishing the European Food Safety Authority and Laying down Procedures in Matters of Food Safety, 178/2002/EC; Official Journal, L 31, 1.2.2002; European Commission: Bruxelles, Belgium, 2002.

17. Patel, S.; Dora, M.; Hahladakis, J.N.; Iacovidou, E. Opportunities, challenges and trade-offs with decreasing avoidable food waste in the UK. Waste Manag. Res. 2021, 39, 473-488. [CrossRef]

18. FAO. Definitional Framework of food loss. SAVE FOOD: Global Initiative on Food Loss and Waste Reduction; Working paper; Food and Agriculture Organization of the United Nations: Rome, Italy, 2014. Available online: http://www.fao.org/fileadmin/user_ upload/save-food/PDF/FLW_Definition_and_Scope_2014.pdf (accessed on 24 April 2021).

19. Ishangulyyev, R.; Kim, S.; Lee, S.H. Understanding Food Loss and Waste-Why Are We Losing and Wasting Food? Foods 2019, 8, 297. [CrossRef]

20. FAO; IFAD; WFP. Food Loss Analyses to Identify Major Causes of Losses and to Recommend Solutions to Reduce Post-Harvest Loss-Grain Supply Chains in Burkina Faso; Technical Brief; The Democratic Republic of the Congo and Uganda: Rome, Italy, 2021. Available online: http:/ / www.fao.org/3/cb1167en/cb1167en.pdf (accessed on 24 April 2021).

21. Chaboud, G.; Daviron, B. Food losses and waste: Navigating the inconsistencies. Glob. Food Secur. 2017, 12, 1-7. [CrossRef]

22. EU Platform on Food Losses and Food Waste. Recommendations for Action in Food Waste Prevention. Developed by the EU Platform on Food Losses and Food Waste. 2019. Available online: https://ec.europa.eu/food/sites/food/files/safety/docs/fs_ eu-actions_action_implementation_platform_key_recommendations.pdf (accessed on 24 April 2021).

23. Gustafson, S. FAO SOFA Report 2019: New Insights into Food Loss and Waste. International Food Policy Research Institute (Issue Post 22 October 2019). 2019. Available online: https: / / wle.cgiar.org/fao-sofa-report-2019-new-insights-food-loss-and-waste (accessed on 24 April 2021).

24. FUSIONS. FUSIONS Definitional Framework for Food Waste. Full Report. Reducing Food Waste through Social Innovation. 2014. Available online: https:/ / www.eu-fusions.org/phocadownload/Publications/FUSIONS\%20Definitional\%20Framework\%20 for\%20Food\%20Waste\%202014.pdf (accessed on 24 April 2021).

25. Mesterházy, Á.; Oláh, J.; Popp, J. Losses in the Grain Supply Chain: Causes and Solutions. Sustainability 2020, 12, 2342. [CrossRef]

26. Hammond, S.; Brown, J.; Burger, J.; Flanagan, T.; Fristoe, T.; Mercado-Silva, N.; Nekola, J.; Okie, J. Food Spoilage, Storage, and Transport: Implications for a Sustainable Future. BioScience 2015, 65, 758-768. [CrossRef]

27. Edmonds, G. Wasted time: The Price of Poor Access; Development Policies Department, International Labour Office: Geneva, Switzerland, 1998.

28. Liliane, T.; Mutengwa, C. Factors Affecting Yield of Crops, Agronomy_Climate Change E Food Security; IntechOpen: Amanullah, Afghanistan, 2020. Available online: https://www.intechopen.com/books/agronomy-climate-change-food-security/factorsaffecting-yield-of-crops (accessed on 24 April 2021). [CrossRef]

29. Johnson, L.; Bloom, J.; Dunning, R.; Gunter, C.; Boyette, M.; Creamer, N. Farmer harvest decisions and vegetable loss in primary production. Agric. Syst. 2019, 176, 102672. [CrossRef] 
30. Rojas-Downing, M.M.; Nejadhashemi, A.P.; Harrigan, T.; Woznicki, S.A. Climate change and livestock: Impacts, adaptation, and mitigation. Clim. Risk Manag. 2017, 16, 145-163. [CrossRef]

31. FAO. The State of Food Insecurity in the World. How Does International Price Volatility Affect Domestic Economies and Food Security? Food and Agriculture Organization of the United Nations: Rome, Italy, 2011. Available online: http://www.fao.org/3/i2330e/i2 330e.pdf (accessed on 24 April 2021).

32. Oosterkamp, E.; Van der Sluis, A.; van Geffen, L.; Aramyan, L.; Bos-Brouwers, H. Cosmetic Aspects in Specific Marketing Standards for Fruit and Vegetables; Removing Cosmetic Aspects from the EU Marketing Standards: Implications for the Market and Impact on Food Waste; Memorandum 2019-014; Wageningen University \& Research: Wageningen, The Netherlands, 2019. Available online: https: / / edepot.wur.nl/503631 (accessed on 24 April 2021).

33. Stuart, T. Waste: Uncovering the Global Food Scandal; W.W. Norton \& Co.: London, UK, 2009.

34. Eggersdorfer, M.; Kraemer, K.; Cordaro, J.B.; Fanzo, J.; Gibney, M.; Kennedy, E.; Labrique, A.; Steffen, J. Good Nutrition: Perspectives for the 21st Century; Karger: Basel, Switzerland, 2016; pp. 45-59. [CrossRef]

35. Mena, C.; Adenso-Diaz, B.; Yurt, O. The causes of food waste in the supplier-retailer interface: Evidences from the UK and Spain. Resour. Conserv. Recycl. 2011, 55, 648-658. [CrossRef]

36. Bräutigam, K.R.; Jörissen, J.; Priefer, C. The extent of food waste generation across EU-27: Different calculation methods and the reliability of their results. Waste Manag. Res. 2014, 32, 683-694. [CrossRef] [PubMed]

37. Papargyropoulou, E.; Steinberger, J.K.; Wright, N.; Lozano, R.; Padfield, R.; Ujang, Z. Patterns and Causes of Food Waste in the Hospitality and Food Service Sector: Food Waste Prevention Insights from Malaysia. Sustainability 2019, 11, 6016. [CrossRef]

38. Toma, L.; Costa Font, M.; Thompson, B. Impact of consumers' understanding of date labelling on food waste behaviour. Oper. Res. 2020, 20, 543-560. [CrossRef]

39. FUSIONS. Food Waste Quantification Manual to Monitor Food Waste Amounts and Progression. Reducing Food Waste through Social Innovation. Final Document. 2016. Available online: https://www.eu-fusions.org/phocadownload/Publications/ FUSIONS\%20Food\%20Waste\%20Quantification\%20Manual.pdf (accessed on 24 April 2021).

40. FAO. SDG 12.3.1: Global Food Loss Index; Food and Agriculture Organization of the United Nations: Rome, Italy, 2018. Available online: http:/ / www.fao.org/3/CA2640EN/ca2640en.pdf (accessed on 24 April 2021).

41. UNEP. Food Waste Index Report 2021; United Nations Environment Programme: Nairobi, Kenya, 2021. Available online: https: / / www.unep.org/resources/report/unep-food-waste-index-report-2021 (accessed on 24 April 2021).

42. FAO. Evaluation of Micronutrient Losses from Postharvest Food Losses (PHL) in Kenya, Cameroon and India-Implications on Micronutrient Deficiencies in Children under 5 Years of Age; Food and Agriculture Organization of the United Nations: Rome, Italy, 2019. Available online: http:/ / www.fao.org/fileadmin/user_upload/food-loss-reduction/CoP_English/Final_version_FLW-Nutrition._ppt_ .pdf (accessed on 24 April 2021).

43. Buzby, J.C.; Hyman, J. Total and per capita value of food loss in the United States. Food Policy 2012, 37, 561-570. [CrossRef]

44. Eriksson, M.; Strid, I.; Hansson, P.-A. Food losses in six Swedish retail stores: Wastage of fruit and vegetables in relation to quantities delivered. Resour. Conserv. Recycl. 2012, 68, 14-20. [CrossRef]

45. Hanson, C.; Mitchell, P. The Business Case for Reducing Food Loss and Waste; Champions 12.3; World Resources Institute: Washington, DC, USA, 2017. Available online: https:// champions123.org/sites/default/files/2020-08/business-case-for-reducing-food-lossand-waste.pdf (accessed on 24 April 2021).

46. Martínez, Z.N.; Menacho, P.Z.; Pachón-Ariza, F. Food loss in a hungry world, A problem? Agron. Colomb. 2014, 32, 283-293. [CrossRef]

47. FAO. Global Agriculture towards 2050. 2009. Available online: http://www.fao.org/fileadmin/templates/wsfs/docs/Issues_ papers/HLEF2050_Global_Agriculture.pdf (accessed on 24 April 2021).

48. Springmann, M.; Clark, M.; Mason-D'Croz, D.; Wiebe, K.; Bodirsky, B.L.; Lassaletta, L.; de Vries, W.; Vermeulen, S.J.; Herrero, M.; Carlson, K.M.; et al. Options for keeping the food system within environmental limits. Nature 2018, 562, 519-525. [CrossRef]

49. Vågsholm, I.; Arzoomand, N.S.; Boqvist, S. Food Security, Safety, and Sustainability-Getting the Trade-Offs Right. Front. Sustain. Food Syst. 2020, 4, 16. [CrossRef]

50. Thornsbury, S. Impacts of Reducing Food Loss and Waste on Food Prices and Farm Incomes. In Reducing Impacts of Food Loss and Waste: Proceedings of a Workshop; Whitacre, P.T., Kameyama, E., Carrero-Martínez, F., Eds.; National Academies Press: Washington, DC, USA, 2019.

51. Veraart, F. Agriculture and Foods: Overproduction and Overconsumption. In Well-Being, Sustainability and Social Development; Springer: Cham, Switzerland, 2018. [CrossRef]

52. Conrad, Z.; Niles, M.T.; Neher, D.A.; Roy, E.D.; Tichenor, N.E.; Jahns, L. Relationship between food waste, diet quality, and environmental sustainability. PLoS ONE 2018, 13, e0195405. [CrossRef]

53. Okawa, K. Market and Trade Impacts of Food Loss and Waste Reduction; OECD Food, Agriculture and Fisheries Papers, No. 75; OECD Publishing: Paris, France, 2015. [CrossRef]

54. Porat, R.; Lichter, A.; Terry, L.A.; Harker, R.; Buzby, J. Postharvest losses of fruit and vegetables during retail and in consumers' homes: Quantifications, causes, and means of prevention. Postharvest Biol. Technol. 2018, 139, 135-149. [CrossRef]

55. Rutten, M.; Kavallari, A. Can reductions in agricultural food losses avoid some of the trade-offs involved when safeguarding domestic food security? A case study of the Middle East and North Africa. In Proceedings of the 16th Annual Conference on Global Economic Analysis, Shanghai, China, 12-14 June 2013. 
56. Global Panel. Future Food Systems: For People, Our Planet, and Prosperity. 2020. The Global Panel on Agriculture and Food Systems for Nutrition Report. Foresight 2.0. Available online: https://www.glopan.org/foresight2/ (accessed on 24 April 2021).

57. Röös, E.; Mie, A.; Wivstad, M.; Salomon, E.; Johansson, B.; Gunnarsson, S.; Wallenbeck, A.; Hoffmann, R.; Nilsson, U.; Sundberg, C.; et al. Risks and opportunities of increasing yields in organic farming. A review. Agron. Sustain. Dev. 2018, 38, 14. [CrossRef]

58. UN. Tier Classification for Global SDG Indicators: 17 July 2020. 2020. Available online: https://unstats.un.org/sdgs/files/Tier\% 20Classification\%20of\%20SDG\%20Indicators_17\%20July\%202020_web.v2.pdf (accessed on 24 April 2021).

59. Gasper, D.; Shah, A.; Tankha, S. The Framing of Sustainable Consumption and Production in SDG 12. Glob. Policy 2019, 10, 83-95. [CrossRef]

60. FAO. Food Wastage Footprint. Impats on Natral Resource; Summary Report; Food and Agriculture Organization of the United Nations: Rome, Italy, 2013. Available online: http:/ /www.fao.org/3/i3347e/i3347e.pdf (accessed on 24 April 2021).

61. Cattaneo, A.; Federighi, G.; Vaz, S. The environmental impact of reducing food loss and waste: A critical assessment. Food Policy 2021, 98, 101890. [CrossRef]

62. Litskas, V.D.; Platis, D.P.; Anagnostopoulos, C.D.; Tsaboula, A.C.; Menexes, G.C.; Kalburtji, K.L.; Stavrinides, M.C.; Mamolos, A.P. Chapter 3-Climate change and agriculture: Carbon footprint estimation for agricultural products and labeling for emissions mitigation. In Sustainability of the Food System; Betoret, N., Betoret, E., Eds.; Academic Press: Cambridge, MA, USA, 2020; pp. 33-49.

63. Wunderlich, S.M.; Martinez, N.M. Conserving natural resources through food loss reduction: Production and consumption stages of the food supply chain. Int. Soil Water Conserv. Res. 2018, 6, 331-339. [CrossRef]

64. Ding, G.K.C.; Ghosh, S. Sustainable Water Management-A Strategy for Maintaining Future Water Resources. In Encyclopedia of Sustainable Technologies; Abraham, M.A., Ed.; Elsevier: Oxford, UK, 2017; pp. 91-103.

65. Čuček, L.; Klemeš, J.J.; Kravanja, Z. Chapter 5-Overview of environmental footprints. In Assessing and Measuring Environmental Impact and Sustainability; Klemeš, J.J., Ed.; Butterworth-Heinemann: Oxford, UK, 2015; pp. 131-193.

66. Ritchie, H.; Roser, M. Environmental Impacts of Food Production. Published Online at OurWorldInData.org. 2020. Available online: https: / / ourworldindata.org/environmental-impacts-of-food (accessed on 24 April 2021).

67. Beretta, C.; Stoessel, F.; Baier, U.; Hellweg, S. Quantifying food losses and the potential for reduction in Switzerland. Waste Manag. 2013, 33, 764-773. [CrossRef]

68. Holka, M.; Bieńkowski, J. Carbon Footprint and Life-Cycle Costs of Maize Production in Conventional and Non-Inversion Tillage Systems. Agronomy 2020, 10, 1877. [CrossRef]

69. World Bank. Addressing Food Loss and Waste: A Global Problem with Local Solutions; World Bank: Washington, DC, USA, 2020. Available online: https:/ / openknowledge.worldbank.org/handle/10986/34521 (accessed on 24 April 2021).

70. Garske, B.; Heyl, K.; Ekardt, F.; Weber, L.M.; Gradzka, W. Challenges of Food Waste Governance: An Assessment of European Legislation on Food Waste and Recommendations for Improvement by Economic Instruments. Land 2020, 9, 231. [CrossRef]

71. Borrello, M.; Caracciolo, F.; Lombardi, A.; Pascucci, S.; Cembalo, L. Consumers' Perspective on Circular Economy Strategy for Reducing Food Waste. Sustainability 2017, 9, 141. [CrossRef]

72. Pouikli, K. Concretising the role of extended producer responsibility in European Union waste law and policy through the lens of the circular economy. ERA Forum 2020, 20, 491-508. [CrossRef]

73. Jha, S.; Kaechele, H.; Lana, M.; Amjath-Babu, T.S.; Sieber, S. Exploring Farmers' Perceptions of Agricultural Technologies: A Case Study from Tanzania. Sustainability 2020, 12, 998. [CrossRef]

74. Chegere, M.J. Post-harvest losses reduction by small-scale maize farmers: The role of handling practices. Food Policy 2018, 77, 103-115. [CrossRef]

75. WRAP. Strategies to Achieve Economic and Environmental Gains by Reducing Food Waste; Final Report; WRAP: Banbury, UK, 2015. Available online: https://www.wrap.org.uk/sites/files/wrap/Strategies $\% 20$ to $\% 20$ achieve $\% 20$ economic $\% 20$ and $\% 20$ environmental\%20gains\%20(1).pdf (accessed on 24 April 2021).

76. ReFED. A Roadmap to Reduce, U.S. Food Waste by 20 Percent. Rethink Food Waste. Through Economics and Data. 2016. Available online: https://www.refed.com/downloads/ReFED_Report_2016.pdf (accessed on 24 April 2021).

77. Delgado, L.; Schuster, M.; Torero, M. Quantity and quality food losses across the value Chain: A Comparative analysis. Food Policy 2021, 98, 101958. [CrossRef]

78. European Commission. Farm to Fork Strategy. For a Fair, Healthy and Environmentally-Friendly Food System. 2020. Available online: https: / / ec.europa.eu/food/sites/food/files/safety/docs/f2f_action-plan_2020_strategy-info_en.pdf (accessed on 24 April 2021).

79. Caldeira, C.; De Laurentiis, V.; Sala, S. Assessment of Food Waste Prevention Actions; EUR 29901 EN; Publications Office of the European Union: Luxembourg, 2019; ISBN 978-92-76-12388-0.

80. IRRI, Grain Storage: The IRRI Super Bag. Rice Science for a Better World. Rice Fact Sheets. 2005. Available online: http: //www.knowledgebank.irri.org/images/docs/fs_how_to_use_the_super_bag.pdf (accessed on 24 April 2021).

81. Sugri, I.; Maalekuu, B.K.; Kusi, F.; Gaveh, E. Quality and Shelf-life of Sweet Potato as Influenced by Storage and Postharvest Treatments. Trends Hortic. Res. 2017, 7, 1-10. [CrossRef]

82. Kumar, D.; Kalita, P. Reducing Postharvest Losses during Storage of Grain Crops to Strengthen Food Security in Developing Countries. Foods 2017, 6, 8. [CrossRef] 
83. Gunders, D. Wasted: How America Is Losing Up to 40 Percent of Its Food from Farm to Fork to Landfill. Natural Resources Defense Council. NRDC ISSUE PAPER. 2012. Available online: https://www.nrdc.org/sites/default/files/wasted-food-IP.pdf (accessed on 24 April 2021).

84. TESCO. New Packaging That Will Keep Fruit and Vegetables Fresher for Days Longer. 2012. Available online: https://www. tescoplc.com/news/2012/new-packaging-that-will-keep-fruit-and-vegetables-fresher-for-days-longer/ (accessed on 20 January 2021).

85. WRAP. Waste Prevention Case Studies. Exemplar Case Studies of How Businesses Have Taken Action to Reduce Waste in Their Food and Drink Supply Chains. 2019. Available online: https://archive.wrap.org.uk/sites/files/wrap/Waste\%20prevention\%20 case\%20studies_0.pdf (accessed on 24 April 2021).

86. Wakeland, W.; Cholette, S.; Venkat, K. Food transportation issues and reducing carbon footprint. In Green Technologies in Food Production and Processing; Food Engineering Series; Boye, J., Arcand, Y., Eds.; Springer: Boston, MA, USA, 2012. [CrossRef]

87. Wang, M.; Kumar, V.; Ruan, X.; Saad, M.; Garza-Reyes, J.A.; Kumar, A. Sustainability concerns on consumers' attitude towards short food supply chains: An empirical investigation. Oper. Manag. Res. 2021, 1-17. [CrossRef]

88. FAO. Reducing the Food Wastage Footprint; Toolkit; Food and Agriculture Organization of the United Nations: Rome, Italy, 2013. Available online: http:/ / www.fao.org/3/i3342e/i3342e.pdf (accessed on 24 April 2021).

89. Hecht, A.A.; Neff, R.A. Food Rescue Intervention Evaluations: A Systematic Review. Sustainability 2019, 11, 6718. [CrossRef]

90. Delshammar, T.; Brincker, S.; Skaarup, K.; Urban Swart Haaland, L. Rooftop Farming Policy. In Rooftop Urban Agriculture. Urban Agriculture; Orsini, F., Dubbeling, M., de Zeeuw, H., Gianquinto, G., Eds.; Springer: Cham, Switzerland, 2017. [CrossRef]

91. Flanagan, K.; Robertson, K.; Hanson, C. Reducing Food Loss and Waste: Setting a Global Action Agenda; World Resources Institute: Washington, DC, USA, 2019. Available online: https://files.wri.org/d8/s3fs-public/reducing-food-loss-waste-global-actionagenda_1.pdf (accessed on 11 May 2021).

92. Schanes, K.; Dobernig, K.; Gözet, B. Food waste matters-A systematic review of household food waste practices and their policy implications. J. Clean. Prod. 2018, 182, 978-991. [CrossRef]

93. Raikos, A.; Gassin, A.-L. EU Action to Promote Better Understanding and Use of Date Marking. Unit E1, Food Information and Composition, Food Waste. EU Platform on Food Losses and Food Waste. 2018. Available online: https://ec.europa.eu/food/ sites/food/files/safety/docs/fw_eu-platform_20180420_sub-dm_pres-01.pdf (accessed on 24 April 2021).

94. UNEP. Foodkit. Our Global Anti-Food Waste Campaign Toolkit. www.thinkeatsave.org Reduce Your Foodprint. 2018. Available online: https: / / wedocs.unep.org/bitstream/handle/20.500.11822/25183/TES_FoodKit\%20ToolKit_WEB.pdf?sequence=1\& isAllowed=y (accessed on 24 April 2021).

95. FUSIONS. Recommandations and Guidelines for a Common European Food Waste Policy Framework. Final Version. 2016. Available online: https://www.eu-fusions.org/phocadownload/Publications/D3.5\%20recommendations\%20and\%20guidelines\% 20food\%20waste\%20policy\%20FINAL.pdf (accessed on 24 April 2021).

96. COMPASS Group. Reducing Risk and Driving Growth. Corporate Responsibility Report 2016. 2016. Available online: https: / / www.compass-group.com/documents/Compass_CR16_Report_Final.pdf (accessed on 24 April 2021).

97. CPIE. Comment Réduire le Gaspillage Alimentaire au Sein de sa Restauration Collective? Eléments de Méthode \& Recueil de Pratiques Auprès des CPIE. Centres Permanents D'inititives Pour L'environnment. 2015. Available online: https:/ /www.cpie.fr/ cpie/ contenu.aspx?ID=191266 (accessed on 24 April 2021).

98. Clowes, A.; Mitchell, P.; Hanson, C. The Business Case for Reducing Food Loss and Waste: Hotels. A Report on Behalf of Champions 12.3. 2018. Available online: https:/ / www.wrap.org.uk/sites/files/wrap/Hotels_The $\% 20$ Business $\% 20$ Case $\% 20 f o r \%$ 20Reducing\%20Food\%20Waste.pdf (accessed on 24 April 2021).

99. UNEP. Prevention and Reduction of Food and Drink Waste in Businesses and Households—Guidance for Governments, Local Authorities, Businesses and Other Organisations, Version 1.0. 2014. Available online: http://www.fao.org/fileadmin/user_ upload/save-food/PDF/Guidance-content.pdf (accessed on 24 April 2021).

100. Io Potentino ONLUS. \#LA166 - La Birra che Nasce dal Pane. 2020. Available online: https:/ /www.iopotentino.it/la166-la-birrache-nasce-dal-pane/ (accessed on 23 April 2021).

101. Al Bloushi, B.G.; Ahmad, S.Z.; Mfarrej, M.F.B. Tadweer: Improving municipal solid waste sustainability practices. Emerald Emerg. Mark. Case Stud. 2020, 10, 1-26. [CrossRef]

102. Styles, D.; Schoenberger, H.; Galvez-Martos, J.-L. Best Practice Application of LCM by Retailers to Improve Product Supply Chain Sustainability. In Towards Life Cycle Sustainability Management; Finkbeiner, M., Ed.; Springer: Dordrecht, The Netherlands, 2011; pp. 217-228. [CrossRef] 